\title{
DEPRESSION IN OLDER PEOPLE DURING THE COVID-19 CURFEW
}

\author{
Tahsin Barış DEGER ${ }^{1}$, Huri Seval GONDEREN CAKMAK ${ }^{2}$, Emin \\ BOZKURT $^{3}$, Bedri EMINSOY ${ }^{4}$
}

\footnotetext{
${ }^{1}$ Department of Gerontology, Faculty of Health Science, Çankırı Karatekin University, Çankırı, Turkey

${ }^{2}$ Department of Geriatric Care Services, Eldivan Vocational School of Health Services, Çankırı Karatekin University, Çankırı, Turkey

${ }^{3}$ Department of Veterinary, Eldivan Vocational School of Health Services, Çankırı Karatekin University, Çankırı, Turkey

${ }^{4}$ Department of Child Care and Youth Services, Eldivan Vocational School of Health Services, Çankırı Karatekin University, Çankırı, Turkey.
}

Address for Correspondence: Tahsin Baris Deger, E-mail: tahsinbarisd@karatekin.edu.tr / drbarisdeger@gmail.com

Received: 20.12.2020; Accepted: 30.03.2021; Available Online Date: 27.05.2021

(C) Copyright 2021 by Dokuz Eylül University, Institute of Health Sciences - Available online at https://dergipark.org.tr/en/pub/jbachs

Cite this article as: Deger TB, Gonderen-Cakmak HS, Bozkurt E, Eminsoy B. Depression in older people during the COVID-19 curfew. J Basic Clin Health Sci 2021; 2: 6-14.

\begin{abstract}
Purpose: Curfew was declared for the people 65 years and older to protect from the COVID-19 pandemic by the government in Turkey on 21 March 2020. The aim of this study is to determine the depression levels, factors affecting depression, concerns about COVID-19 infection, thoughts about curfew, lifestyles and ways of meeting their needs of the older adults during the curfew.

Methods: In the first method, the data of the study were collected by the researchers by contacting the relatives of our university health department students by phone or video interview, and in the second, via Google Forms by the link of the study shared on social networks and online platform and a total of 1311 older people were included. Older adult information form and Geriatric Depression Scale Short Form (GDS-15) were used. Mann Whitney-U Test, Kruskal Wallis Test and Multivariate Logistic Regression analysis were conducted.

Results: Prevalence of depression was measured as $44.2 \%$ in the participants. Being aged 85 and over, illiteracy, living alone, having chronic disease, previous psychiatric diagnosis, anxiety about infection with COVID-19 and disapprove of curfew decision significantly increased the depression levels in older adults. Conclusion: The curfew during the COVID-19 pandemic increased the depression level in older adults compared to before the curfew.
\end{abstract}

Keyword: COVID-19, curfew, depression, older adults, pandemic

\section{INTRODUCTION}

The COVID-19 outbreak, which started in December 2019 in the Wuhan region of China, spread rapidly all over the country and then throughout the world (1). COVID-19 is transmitted human to human by respiratory droplets and contact. (2). Therefore, isolation at home seems to be an effective method. Countries implemented national policies to minimize pandemic harm to their citizens. (3). One of these policies in our country was for the older adults, 
because older people constituted one of the most important risk groups for this disease (4). Curfew was declared in Turkey on March 21 for individuals aged 65 years and older (5).

The curfew imposed on the older adults led to loneliness and social isolation. Even in studies before the COVID-19 pandemic started, social isolation and loneliness were reported to increase depression and anxiety levels in the older adults (6). Geriatric depression is a major public health problem and risk factor that can make diseases worse, especially among people with chronic diseases like cardiovascular diseases and diabetes mellitus (7). Depression in the older adult affects people with cognitive impairment, chronic disease more and increases mortality, in addition to causing suffering, family unrest and disability (8).

The curfew was declared in Turkey continued for about 70 days. The 50 days were full restrictions, the older adults were never able to go out, in the last 20 days they were allowed to go out for 3-4 hours, once a week. The curfew for the older adults was ended on 1 of June. The number of cases decreased, the society took a good breath in the summer months when the restrictions were lifted, but with the autumn, the number of cases started to increase in our country as in the whole world (9). The arrival of the second wave of the pandemic forced the government to restricts again. The restriction for the elderly was again imposed, but it was not a full restriction as in first wave. They were allowed to go out at certain times every day (10).

In this study, we aimed to measure the depression levels of older adult individuals who could not leave home during the COVID-19 curfew (when there are full restrictions in the first wave of the pandemic) in Turkey. We tried to determine the factors affecting depression in the older people during the COVID-19 curfew and the lifestyle of the elderly and what their coping strategies were in this difficult period when they could not leave the house. We tried to determine what they think about pandemic and constraints and who they get support from and how all these factors affect depression levels.

\section{METHODS}

\section{Subjects}

This is a descriptive study which included a total of 1311 community-dwelling older adult individuals throughout Turkey. Our sample consists of older adult individuals who could not leave their home due to the curfew. Participants aged 65 years and over, have capable of easily understanding and answering questions posed by researchers, and who voluntarily accepted to participate in the study were included. According to the $\mathrm{WHO}$, older adults are classified as young elderly, middle elderly and old elderly, respectively aged $65-74,75-84$ and older than 85 years. In this study, we used the older people classification of WHO to group older adults. The 6574 years age group was classified as the first group, the 75-84 years age group was the second group, and the $\geq 85$ years age group was the third group.

Curfew was declared for older people on March 21 in Turkey. We started to collect data on May 12. When we started to collect the data, the older people had stayed at home for 50 days. Our study lasted 18 days and we ended the study on May 30 .

\section{Assessments}

Two forms were used in study. First was an up-todate form created by researchers with questions about the COVID-19 outbreak and the curfew process. Sociodemographic and health data, and life style of older individuals during the curfew were inquired about with this form.

With this form, the views of the participants about the pandemic and constraints, their behaviors and coping strategies during their stay at home were determined. Table 1 and Table 3 can be viewed to reach the questions in this form.

The second form was the Geriatric Depression Scale Short Form (GDS-15). GDS-15 is a scale which included 15 items consisting of 'yes' and 'no' answers with total points of 15 (11). The study about the validity and reliability of GDS-15 was completed in Turkey with older adults. A cut-off value of 5 points and over is accepted as depression (12). A cut-off of $>5$ is "suggestive" of depression but requires follow up with a comprehensive assessment while $>9$ is moderate and $>12$ is severe indicative of depression (13). Accordingly, depression levels in our study are determined.

\section{Procedure}

Face-to-face survey interviews were not possible as older adults were not allowed to go out on the streets and travel was not possible due to restrictions in the country. It was also necessary to reach older people living in other parts of the country, both in urban and rural areas, with different education levels and different socioeconomic status. Two different methods were used for this. 
The first method; our students were contacted by the researchers and the lists of their grandparents and elderly relatives who voluntarily agreed to participate in the study were asked. These students were the students of our university's health sciences faculty and health services vocational school. During the period of the study, education at the university was suspended due to the restrictions and our students were staying in their hometown in different parts of the country. Voluntary relatives of students studying in health and geriatrics care departments at some other universities in the country were also added to these lists. The researchers personally contacted the volunteer participants on the list and conducted the surveys. Those who had a smart phone or computer were contacted visually, and those who could not use the internet or were illiterate via phone. The questionnaires were conducted by the researchers by taking verbal consent from the participants and marking the answers on the google form.

The second method shared the link to the study on online platforms and social networks and older individuals who volunteered filled the questionnaires. This second data collection technique was carried out via an online platform using Google Forms. In this method, informed consent was obtained from the participants via google form. Since the names and personal information of the participants were not on the form, the privacy and confidentiality of the person was protected.

The study was submitted and approved by the Ethics Committee of Çankırı Karatekin University, Turkey (Reference Number: 2020/196, Date: 2020, April 17). The study was conducted in accordance with the Declaration of Helsinki. All participants provided informed consent before being included in the study as a participant. Approval was obtained for this research by applying to the COVID-19 Scientific Research Platform of the Republic of Turkey, Ministry of Health (Reference Number: 2020-0512T23_30_49).

\section{Statistical analysis}

Analysis of the data was done using SPSS 25 package program. Descriptive statistics (mean, standard deviation, number and percentile) are given for categorical and continuous variables in the study. The dependent variable of the study is GDS-15 total scores, and independent variables are answers to sociodemographic and other questions in Form 1. When comparing the scores of the scale, which is the

Table 1: Comparison of the descriptive characteristics of the elderly individuals and the mean scores on the geriatric depression scale short form (GDS-15)

\begin{tabular}{|c|c|c|c|c|c|c|}
\hline Variant & Groups & $\mathbf{N}$ & $\%$ & MSTS & TS & $\mathbf{P}$ \\
\hline \multirow{3}{*}{ Age } & $65-74$ years & 946 & 72.2 & $4.51 \pm 3.53^{a}$ & \multirow{3}{*}{14.718} & \multirow{3}{*}{$0.001 \psi^{*}$} \\
\hline & 75 - 84 years & 268 & 20.4 & $4.63 \pm 3.51^{a}$ & & \\
\hline & $\geq 85$ & 97 & 7.4 & $5.85 \pm 3.45^{b}$ & & \\
\hline \multirow{2}{*}{ Gender } & Female & 867 & 66.1 & $4.94 \pm 3.61$ & \multirow{2}{*}{-4.221} & \multirow{2}{*}{$0.001 €^{*}$} \\
\hline & Male & 444 & 33.9 & $4.05 \pm 3.31$ & & \\
\hline \multirow{6}{*}{ Education status } & Illiterate & 388 & 29.6 & $5.36 \pm 3.72^{a}$ & \multirow{6}{*}{38.273} & \multirow{6}{*}{$0.001 \psi^{*}$} \\
\hline & Literate & 240 & 18.3 & $4.70 \pm 3.37^{b}$ & & \\
\hline & Primary school & 391 & 29.8 & $4.43 \pm 3.29^{b}$ & & \\
\hline & Middle School & 97 & 7.4 & $3.94 \pm 3.08^{c}$ & & \\
\hline & High school & 77 & 5.9 & $3.20 \pm 3.36^{d}$ & & \\
\hline & University & 118 & 9.0 & $4.32 \pm 4.02^{b}$ & & \\
\hline \multirow{5}{*}{ Living with } & Alone & 208 & 15.9 & $5.12 \pm 3.36^{a}$ & \multirow{5}{*}{40.771} & \multirow{5}{*}{$0.001 \psi^{*}$} \\
\hline & Spouse & 481 & 36.7 & $3.92 \pm 3.37^{b}$ & & \\
\hline & Spouse-child & 243 & 18.5 & $4.91 \pm 3.74^{c}$ & & \\
\hline & Children & 304 & 23.2 & $4.88 \pm 3.50^{d}$ & & \\
\hline & Relative/carer & 75 & 5.7 & $6.00 \pm 3.76^{\mathrm{e}}$ & & \\
\hline \multirow{2}{*}{ Chronic disease } & Yes & 998 & 76.1 & $4.90 \pm 3.53$ & \multirow{2}{*}{-5.454} & \multirow{2}{*}{$0.001^{€ *}$} \\
\hline & No & 313 & 23.9 & $3.78 \pm 3.43$ & & \\
\hline \multirow{2}{*}{ Psychiatric diagnosis } & Yes & 141 & 10.8 & $7.14 \pm 3.75$ & \multirow{2}{*}{-8.228} & \multirow{2}{*}{$0.001 \epsilon^{*}$} \\
\hline & No & 1170 & 89.2 & $4.34 \pm 3.39$ & & \\
\hline
\end{tabular}

TS: Test statistics, MSTS: Mean of scale total score (GDS-15), a,b,c,d,e There was no significant difference between the same letters, $€$ Mann Whitney-U Test, ${ }^{*}$ Kruskal Wallis Test; *Statistically significant $p<0.05$ 
dependent variable, the Mann Whitney-U Test was used in those with 2 independent sociodemographic characteristics, and the Kruskal Wallis Test was used in those with 3 or more categories. In Multivariate Binary Logistic Regression analysis, our main motivation was to evaluate the risk of depressed or non-depressed participants according to the GDS-15 score, multivariably, according to other socioeconomic variables and scores. When the part where the relationship between depression and gender is examined in the discussion section, it becomes clear how important the Multivariate Logistic Regression Analysis is in such a study. For the results of the statistical analysis, $p$-values of $<0.05$ were considered significant.

\section{RESULTS}

In this study, we used the older people classification of WHO to group older adults. According to this, percentages of older adults were $72.2 \%, 20.4 \%$ and $7.4 \%$, respectively as young elderly, middle elderly and old elderly. All the descriptive features are given in Table 1. Descriptive characteristics of the participants and GDS-15 mean scores were compared. The relationships between geriatric depression and age older than 85 years, female sex, illiteracy, living alone, having one and more chronic disease and presence of previous psychiatric were statistically significant $(p<0.05)$ (Table 1$)$.

In our study, a short form of the Geriatric Depression Scale was used and the depression levels of older individuals were measured. The cut-off for the validity and reliability studies done on this scale for the older people living in Turkey was accepted as 5 and above (12). According to our study, the frequency of depression among the older adults during the COVID 19 curfew was found to be $44.2 \%$ (Table 2). In a recent study published in 2019 regarding the cut-off value of the scale, the cut-off value was accepted as
5 and above and the level of depression was divided into categories (13). Accordingly, depression levels in our study are given in the table (Table 2) Table 2.

The relationship between depression levels and thoughts about COVID-19 disease, lifestyles, experiences, methods of meeting the needs, the ability to use social media and shop online of the aged individuals during the curfew were determined (Table 3). All variables in the study were reviewed with the multivariate binary logistic regression analysis. The depression level of the individuals over 85 years old was 1.777 times more than the $65-74$ years group $(p<0.05)(O R=1.77,95 \%$ C.I. $=1.068-2.955)$. Illiterate individuals are 1.860 and 2.025 times more likely to be depressed than individuals with primary and middle school education, respectively $(p<0.05)$ $(\mathrm{OR}=0.53,95 \%$ C.I. $=0.305-0.946 ; \mathrm{OR}=0.49,95 \%$ C.I. $=0.253-0.963)$. Illiterate individuals also have 1.834 times higher depression than individuals with high school education $(p<0.05)(O R=0.54,95 \%$ C.I. $=0.300-0.990)$. Older individuals who live alone have 1.502 times more risk of depression than other individuals $(p<0.05)(O R=0.66,95 \%$ C. I. $=0.452$ 0.980 ). While individuals diagnosed with chronic disease have an increased level of depression by 1.896 times, individuals with psychiatric illnesses have an increased level of depression by 3.299 times $(p<0.05)(O R=0.52,95 \%$ C.I. $=0.381-0.729$; OR $=0.30,95 \%$ C.I. $=0.194-0.472$ ). Meanwhile individuals who are afraid of transmission of COVID19 disease have 1.555 times increased level of depression $(p<0.05)(O R=0.64,95 \%$ C.I. $=0.457$ $0.905)$. Individuals who meet their needs together with other family members are 1.862 times more likely to be depressed than individuals who meet their needs using multiple options $(p<0.05)(O R=0.53$, $95 \%$ C.I. $=0.313-0.922)$. All the multivariate logistic regression results were given in Table 4.

Table 2: Depression levels of the elderly according to the Geriatric Depression Scale Short Form (GDS-15)

\begin{tabular}{|l|l|l|l|l|l|}
\hline \multirow{2}{*}{ Depression } & $\begin{array}{l}\text { No } \\
\text { N (\%) }\end{array}$ & \multicolumn{2}{|l|}{$\begin{array}{l}\text { Yes } \\
\text { N (\%) }\end{array}$} & \multirow{2}{*}{ Total } \\
\cline { 2 - 4 } & \multirow{3}{*}{$732(55.8 \%)$} & \multicolumn{2}{|l|}{$579(44.2 \%)$} & \multirow{2}{*}{$1311(100 \%)$} \\
\cline { 3 - 5 } & & Mild & Moderate & Severe & \\
\cline { 3 - 5 } & & $355(27.1 \%)$ & $163(12.4 \%)$ & $61(4.7 \%)$ & \\
\hline
\end{tabular}


Table 3: Comparison of the thoughts about Covid-19 disease of the aged individuals, their lifestyles during the curfew and the mean scores of geriatric depression scale short form (GDS-15)

\begin{tabular}{|c|c|c|c|c|c|c|}
\hline Questions / Answers & & $\mathbf{N}$ & $\%$ & MSTS & TS & $\mathbf{P}$ \\
\hline \multirow{3}{*}{$\begin{array}{l}\text { Are you afraid that } \\
\text { Covid-19 will infect } \\
\text { you? }\end{array}$} & Yes & 1060 & 80.9 & $4.78 \pm 3.52$ & \multirow{3}{*}{-3.413} & \multirow{3}{*}{$0.001^{\epsilon^{\star}}$} \\
\hline & & & & & & \\
\hline & No & 251 & 19.1 & $4.04 \pm 3.55$ & & \\
\hline \multirow{5}{*}{$\begin{array}{l}\text { What are you doing } \\
\text { to prevent the } \\
\text { disease? }\end{array}$} & Wash hands often & 69 & 5.3 & $5.75 \pm 3.49^{\mathrm{a}}$ & \multirow{5}{*}{28.281} & \multirow{5}{*}{$0.001 \psi^{*}$} \\
\hline & Avoid contact with anyone & 344 & 26.2 & $5.31 \pm 3.71^{a}$ & & \\
\hline & Eating and drinking well & 28 & 2.1 & $4.46 \pm 3.88^{a b}$ & & \\
\hline & Airing the room often & 9 & 0.7 & $5.33 \pm 4.06^{a b}$ & & \\
\hline & Apply all & 861 & 65.7 & $4.28 \pm 3.40^{b}$ & & \\
\hline \multirow{3}{*}{$\begin{array}{l}\text { Do you find the } \\
\text { curfew for older } \\
\text { adults is correct? }\end{array}$} & Yes & 1199 & 91.5 & $4.58 \pm 3.50$ & \multirow{3}{*}{-2.040} & \multirow{3}{*}{$0.041^{\epsilon^{*}}$} \\
\hline & & & & & & \\
\hline & No & 105 & 8.0 & $5.44 \pm 3.91$ & & \\
\hline \multirow{2}{*}{$\begin{array}{l}\text { Have you ever been } \\
\text { on the street during } \\
\text { this time? }\end{array}$} & Yes & 411 & 31.4 & $4.93 \pm 3.68$ & \multirow[b]{2}{*}{-1.697} & \multirow[b]{2}{*}{$0.090^{\epsilon}$} \\
\hline & No & 896 & 68.3 & $4.52 \pm 3.46$ & & \\
\hline \multirow{5}{*}{$\begin{array}{l}\text { If yes, for what } \\
\text { purpose did you go } \\
\text { out? }\end{array}$} & Basic food shopping & 122 & 9.3 & $4.71 \pm 3.481$ & \multirow{5}{*}{2.030} & \multirow{5}{*}{$0.730^{\psi}$} \\
\hline & Health and other & 168 & 12.8 & $4.92 \pm 3.66$ & & \\
\hline & Boredom & 33 & 2.5 & $5.69 \pm 4.13$ & & \\
\hline & For walking & 44 & 3.4 & $5.36 \pm 3.94$ & & \\
\hline & For multiple occasions & 84 & 6.4 & $4.66 \pm 3.48$ & & \\
\hline \multirow{7}{*}{$\begin{array}{l}\text { If no, how did you } \\
\text { meet your needs? }\end{array}$} & Household & 341 & 26.0 & $5.07 \pm 3.75$ & \multirow{7}{*}{5.136} & \multirow{7}{*}{$0.400^{\psi}$} \\
\hline & $\begin{array}{l}\text { Children/grandchildren whom I } \\
\text { don't live with }\end{array}$ & 412 & 31.4 & $4.36 \pm 3.24$ & & \\
\hline & Government support & 15 & 1.1 & $4.26 \pm 3.84$ & & \\
\hline & Online shopping & 6 & 0.5 & $4.33 \pm 3.38$ & & \\
\hline & By phone from market & 35 & 2.7 & $4.88 \pm 4.22$ & & \\
\hline & Using multiple options & 198 & 15.1 & $4.69 \pm 3.67$ & & \\
\hline & No answer & 304 & 23.2 & $4.50 \pm 3.48$ & & \\
\hline \multirow{4}{*}{$\begin{array}{l}\text { Which social media } \\
\text { communication tools } \\
\text { do you use? }\end{array}$} & Online platforms & 55 & 4.2 & $4.38 \pm 3.34^{\mathrm{ab}}$ & \multirow{4}{*}{11.143} & \multirow{4}{*}{$0.049 \psi^{*}$} \\
\hline & Social networks & 17 & 1.3 & $4.35 \pm 3.18^{\mathrm{ab}}$ & & \\
\hline & Only phone & 893 & 68.1 & $4.78 \pm 3.51^{\mathrm{a}}$ & & \\
\hline & Use multiple options & 315 & 24.0 & $4.23 \pm 3.61^{b}$ & & \\
\hline \multirow{2}{*}{$\begin{array}{l}\text { Can you shop } \\
\text { online? }\end{array}$} & Yes & 134 & 10.2 & $4.38 \pm 4.06$ & -1.862 & $0.063^{\epsilon}$ \\
\hline & No & 1167 & 89.0 & $4.68 \pm 3.48$ & -1.802 & $0.003^{\circ}$ \\
\hline & Have no credit card & 118 & 9.0 & $4.98 \pm 3.35$ & & \\
\hline If no why? & Can't use the computer & 652 & 49.7 & $4.64 \pm 3.47$ & 3192 & $0.363 \psi$ \\
\hline II no, why? & Other reasons & 318 & 24.3 & $4.60 \pm 3.56$ & 0.192 & \\
\hline & No answer & 223 & 17.0 & $4.5 \pm 3.80$ & & \\
\hline & Shopping & 27 & 2.1 & $4.37 \pm 3.23^{a b}$ & & \\
\hline & Going to hospital & 43 & 3.3 & $5.60 \pm 3.66^{a}$ & & \\
\hline What are the most & Boring at home & 63 & 4.8 & $5.28 \pm 3.79^{a}$ & & \\
\hline difficult things during & Socially & 22 & 1.7 & $6.22 \pm 4.61^{\mathrm{a}}$ & 20.090 & $0.005 \psi^{*}$ \\
\hline the curfew? & Not seeing my relatives & 204 & 15.6 & $3.88 \pm 3.42^{b}$ & & \\
\hline & Inactivity & 115 & 8.8 & $4.79 \pm 3.78^{a}$ & & \\
\hline & Multiple situations & 827 & 63.1 & $4.68 \pm 3.45^{\mathrm{a}}$ & & \\
\hline & None & 616 & 47.0 & $3.58 \pm 3.13^{a}$ & & \\
\hline Choose the status of & Increased smoking & 19 & 1.4 & $6.68 \pm 3.62^{b}$ & & \\
\hline $\begin{array}{l}\text { the following } \\
\text { statements in the }\end{array}$ & Gained weight & 187 & 14.3 & $4.15 \pm 3.37^{c}$ & 159.41 & $0.001 \psi^{*}$ \\
\hline past 2 months? & Having sleep problems & 305 & 23.3 & $5.81 \pm 3.39^{b d}$ & & \\
\hline & Multiple situations & 176 & 13.4 & $6.64 \pm 3.75^{\mathrm{bd}}$ & & \\
\hline
\end{tabular}

TS: Test statistics, MSTS: Mean of scale total score (GDS-15), ${ }^{\mathrm{a}, \mathrm{b}, \mathrm{b}, \mathrm{c}, \mathrm{d}, \mathrm{e}}$ There is no significant difference between the same letters, ${ }^{\epsilon}$ Mann Whitney-U Test, ${ }^{\psi}$ Kruskal Wallis Test; *Statistically significant $p<0.05$ 


\section{DISCUSSION}

In this study, the frequency of depression was found to be $44.2 \%$ in older individuals during curfew process. The frequency of depression was found to be $37.1 \%$ in a study conducted on youth and adults during the COVID-19 outbreak in China (14). In another study conducted during the COVID-19 epidemic process, which also covered all age groups in China, the frequency of depression was found to be $20.1 \%$ (15). The frequency of depression was declared to be $4.5 \%-37.4 \%$ among older individuals aged $14-68$ years, levels of $10.2 \%$ mild, $17.8 \%$ moderate, and $9.1 \%$ severe depression were identified (14). In the present study, these rates were $27.1 \%, 12.4 \%$ and $4.7 \%$, respectively. We attribute the high rates in our study to the fact that we included older individuals in the study and that a curfew was applied to all individuals over 65 years of age in our country. In addition, it is not always correct to diagnose depression for the elderly with mild depression, which was $27.1 \%$ in our study. This is a risk, follow-up and further evaluation are needed. For

Table 4. Investigation of Factors Affecting GDS-15 with Multivariate Binary Logistic Regression Analysis

\begin{tabular}{|c|c|c|c|c|c|c|c|c|}
\hline \multirow{2}{*}{ Groups } & \multirow{2}{*}{ B } & \multirow{2}{*}{ S.E. } & \multirow{2}{*}{ Wald } & \multirow{2}{*}{ df } & \multirow{2}{*}{ Sig. } & \multirow{2}{*}{ OR } & \multicolumn{2}{|c|}{ 95\% C.I. for OR } \\
\hline & & & & & & & \begin{tabular}{l|l} 
Lower & \\
\end{tabular} & per \\
\hline $\begin{array}{c}\text { Age } \\
65-74 \text { years } \pi \\
75-84 \text { years } \\
\geq 85\end{array}$ & $\begin{array}{r}-0.247 \\
0.575\end{array}$ & $\begin{array}{l}0.168 \\
0.260 \\
\end{array}$ & $\begin{array}{l}8.812 \\
2.167 \\
4.906 \\
\end{array}$ & $\begin{array}{l}2 \\
1 \\
1\end{array}$ & $\begin{array}{l}0.012 \\
0.141 \\
0.027^{*}\end{array}$ & $\begin{array}{l}0.781 \\
1.777 \\
\end{array}$ & $\begin{array}{c}0.563(1.77) \\
1.068\end{array}$ & $\begin{array}{l}1.085 \\
2.955 \\
\end{array}$ \\
\hline $\begin{array}{l}\text { Education } \\
\text { Illiterate }{ }^{\pi} \\
\text { Literate } \\
\text { Primary school } \\
\text { Middle school } \\
\text { High school }\end{array}$ & $\begin{array}{l}-0.062 \\
-0.307 \\
-0.621 \\
-0.706 \\
-0.607\end{array}$ & $\begin{array}{l}0.191 \\
0.177 \\
0.288 \\
0.341 \\
0.305 \\
\end{array}$ & $\begin{array}{l}9.493 \\
0.106 \\
3.033 \\
4.640 \\
4.288 \\
3.971 \\
\end{array}$ & $\begin{array}{l}5 \\
1 \\
1 \\
1 \\
1 \\
1\end{array}$ & $\begin{array}{l}0.091 \\
0.745 \\
0.082 \\
0.031 \\
0.038 \text { * } \\
0.046^{*}\end{array}$ & $\begin{array}{l}0.940 \\
0.735 \\
0.537 \\
0.493 \\
0.545 \\
\end{array}$ & $\begin{array}{l}0.646(1.54) \\
0.520(1.92) \\
0.305(3.27) \\
0.253(3.95) \\
0.300(3.33)\end{array}$ & $\begin{array}{l}1.367 \\
1.039 \\
0.946 \\
0.963 \\
0.990\end{array}$ \\
\hline $\begin{array}{c}\text { Living } \\
\text { Living alone }{ }^{\pi} \\
\text { With spouse } \\
\text { Spouse-child } \\
\text { Children }\end{array}$ & $\begin{array}{l}-0.407 \\
-0.087 \\
-0.203 \\
0.572\end{array}$ & $\begin{array}{l}0.197 \\
0.240 \\
0.219 \\
0.331\end{array}$ & $\begin{array}{l}12.495 \\
4.251 \\
0.132 \\
0.857 \\
2.997\end{array}$ & $\begin{array}{l}4 \\
1 \\
1 \\
1 \\
1\end{array}$ & $\begin{array}{c}0.014 \\
0.039 \\
0.716 \\
0.355 \\
0.083\end{array}$ & $\begin{array}{l}0.666 \\
0.916 \\
0.816 \\
1.773\end{array}$ & $\begin{array}{c}0.452(2.21) \\
0.573(1.74) \\
0.531(1.88) \\
0.927(1.7)\end{array}$ & $\begin{array}{l}0.980 \\
1.466 \\
1.255 \\
3.389\end{array}$ \\
\hline Chronic disease & -0.640 & 0.165 & 15.014 & 1 & $0.000^{*}$ & 0.527 & $0.381(2.62)$ & 0.729 \\
\hline Psychiatric illness & -1.194 & 0.226 & 27.795 & 1 & $0.000^{*}$ & 0.303 & $0.194(5.15)$ & 0.472 \\
\hline Fear of Covid-19 & -0.442 & 0.174 & 6.424 & 1 & $0.011^{*}$ & 0.643 & $0.457(2.18)$ & 0.905 \\
\hline $\begin{array}{l}\text { How did you meet your needs } \\
\text { during curfew? } \\
\text { Household }{ }^{\pi} \\
\text { Relatives I don't live with } \\
\text { Government/support group } \\
\text { Online shopping } \\
\text { By phone from market } \\
\text { Using multiple options }\end{array}$ & $\begin{array}{c}-0.092 \\
0.037 \\
-0.403 \\
-0.296 \\
0.274 \\
-0.622\end{array}$ & $\begin{array}{l}0.187 \\
0.644 \\
1.079 \\
0.444 \\
0.221 \\
0.276\end{array}$ & $\begin{array}{l}0.243 \\
0.003 \\
0.139 \\
0.445 \\
1.540 \\
5.075\end{array}$ & $\begin{array}{l}1 \\
1 \\
1 \\
1 \\
1 \\
1\end{array}$ & $\begin{array}{c}0.622 \\
0.955 \\
0.709 \\
0.505 \\
0.215 \\
0.024\end{array}$ * & $\begin{array}{l}0.912 \\
1.037 \\
0.669 \\
0.744 \\
1.315 \\
0.537\end{array}$ & $\begin{array}{c}0.632(1.58) \\
0.294(3.40) \\
0.081(12.34) \\
0.311(3.21) \\
0.853(1.17) \\
0.313(3.19)\end{array}$ & $\begin{array}{l}1.315 \\
3.663 \\
5.539 \\
1.776 \\
2.026 \\
0.922\end{array}$ \\
\hline
\end{tabular}

$\mathrm{OR}=$ Odds ratio; C.I. = confidence interval; $\mathrm{B}=\beta$ value; S.E. $=$ standard error; Wald $=$ method; df $=$ degrees of freedom. Odds ratio for negative output coefficients is calculated as Rate: $1 / e^{\beta}$, ${ }^{*}$ Statistically significant $(p<0.05)$, $\pi$ Indicator (For categorical variables; on each variable, for GDS-15 score; according to the indicator variable, other variables were compared in terms of Odds ratios), (For continuous measurement variables; the increase or decrease in the scores was evaluated in terms of Odds ratio, 1 / $\mathrm{e}^{\beta}$ value was taken for cases where the Odds ratio was negative)

(12). As a result of the $44 \%$ rate in the present study, we see that the COVID-19 outbreak and the curfew process increased the level of depression in the older people.

During the COVID-19 outbreak, a study of adults between the ages of 26 - 60 in Spain identified 9.4\% mild, $5.6 \%$ moderate, $2.1 \%$ severe and $2.9 \%$ very severe signs of depression (16). In a study conducted in China after the outbreak that included individuals the elderly with moderate and severe depression, $12.4 \%$ and $4.7 \%$, it would be correct to say that they are depressed with more confident sentences.

When a study about the frequency of depression among older individuals before the COVID-19 epidemic is examined, the depression levels of the group aged 85 and over were higher than the other older groups (17). In the present study, similar results were found in the older people during the curfew. 
Immobility increases sarcopenia and demineralization in the older adult. These events increase the need for care in the older people creating a greater risk of depression and are more pronounced over 85 years of age.

In a study conducted about youth and adults, no correlation was found between gender and depression during the COVID-19 epidemic (14). However, in another study of adults during the COVID-19 epidemic, levels of depression were higher in females than in males (16). In a study conducted in Spain during the constraints during the COVID-19 pandemic process, depression was studied in all age groups, and the level of depression was found to be higher in both adult and elderly women than men (18). When past studies are examined, it is clearly seen that the frequency of depression in females was higher than in males (19). When we analyze with the Mann Whitney-U Test, our study confirms these findings from other studies, but when we analyze with multivariate binary logistic regression, the gender difference had no effect on depression in the older people during the curfew imposed due to COVID-19. The comparison test of univariate group rank values makes only one assessment independent of other variables by comparing the total scale scores. Regression analysis is a multivariate model that results from the interaction of all variables, according to how they act together. We think that the reason for the equal level of depression in the present study and the high value for this rate in females in previous studies is the absolute equality in living standards of men and women due to the curfew. The result shows that the older adults carry an equal risk of depression under the same living conditions, regardless of gender.

In a study conducted in Korea with a large sample group of adults and older people over the age of 45 , the level of depression decreased as the level of education increased (20). We found similar results in the present study. In the present study, the level of depression in the illiterate older individuals was higher than among those who were primary school, middle school and high school graduates. The COVID-19 curfew was very difficult for the older individuals who were forbidden to leave the house and were illiterate. These individuals could read books and newspapers or use computers in their homes. As expected, the level of depression was high in the aged who could not read.
In a study conducted among the older adults living in the city center of Ankara in our country before the COVID-19 process, a negative correlation was reported between the number of persons in the household and the geriatric depression scale score (21). Similarly, In the present study, the mean geriatric depression scale (GDS-15) of the older adults living alone was higher than for those living with their spouse, children or both their spouse and children. This result is an indication that the older people are protected within the traditional family structure and that family support is very effective in preventing psychological disorders in the older people.

In a study conducted during the COVID-19 epidemic process and involving all age groups, a positive relationship was found between the presence of chronic disease and the level of depression (22). The presence of chronic disease and depression were statistically significant in the present study, which we conducted only for the advanced age group.

We know that the presence of previous psychiatric illness in the COVID-19 epidemic increased depression in all age groups (22). This result did not change in the present study for the older group.

An important effect of the COVID-19 outbreak is the feeling of uncertainty in individuals. Uncertainty increases anxiety in relation to the current problem. Therefore, depression scores were high in individuals with anxiety and there are important connections between anxiety and depression and occurrence of viral diseases (23). In addition, COVID-19 news or seeing someone with the infection increase anxiety and depression. Knowing someone quarantined for Ebola was independently associated with anxiety and depression (24). Similarly, 39\% of the public stated they had anxiety about avian influenza in France (25) while $16 \%$ of the public felt anxious during the early stage of the influenza $A$ (H1N1) outbreak in the Netherlands (26). Higher levels of stress, anxiety, and depression are predicted after a stay at home because imprisonment may tend to produce or intensify these psychological problems (27). Similar to many other studies, depression was higher in those who were worried about getting COVID-19 disease in the present study. The important situations that create anxiety during outbreaks are panic, uncertainty and feelings of being out of control. In this context, individuals who believe curfew is correct may feel safer. Depression scores may be lower as the feeling that the outbreak is under control will reduce anxiety 
of individuals. Individuals who feel socially safe are more optimistic and hopeful about leading their lives (28). In present study, the older people felt safe at home and found the curfew was correct.

The studies reported that the COVID-19 epidemic caused anxiety, depression, sleep quality impairment and increased tobacco consumption in humans (29, 15). Similarly, in the present study, the mean score for depression, which increases smoking and suffers from sleep problems, was high.

\section{Limitations}

There are several limitations in our study. First, there were many restrictions in the country and it was impossible to meet face to face. Second, most of the older adults in the country cannot use the internet and smart phones. Thus, the link we sent online did not reach them or the older adults could not complete the questionnaire. For this reason, the volunteer relatives of our students were called by the researchers and surveys were conducted. Although the study includes a large sample group, it cannot be generalized to the whole society.

\section{Strengths}

The study has many strengths. The most important is that it involved participation of older individuals from all over the country and has a large sample size. These older people were both living in urban and rural area. Also, most of the data collected in the study were reliable and real information because data were collected by researchers who reach the participants via internet or telephone. During the COVID-19 outbreak, schools were closed and students were at home in their own cities and villages. They asked to their grandparents and relatives whether they volunteered to participate in the research and supported the research by giving us a list of participants. Thus, the illiterate older adults were also reached, and the sample covered every segment of the older people in the country.

\section{Suggestions}

The older people population in many countries in the world is increasing rapidly. Countries should be prepared for this. Older people should be registered by the relevant ministries. Electronic health records of the older adults should be recorded. Just like in family medicine practice, every older person should be connected to a gerontologist or public health specialist. In quarantine situations, these professionals should be in constant contact with the older adults by telephone or video chat. During this communication, nurse and psychiatrist support should be provided to the older adults with chronic disease, psychiatric diagnosis or high GDS scores. In pandemic situations, policies that can meet the needs of the older adults should be applied without discrimination of age, taking into account the factors that trigger depression in this article.

\section{CONCLUSION}

In the following years, measures to be taken in case of epidemics will always be on the agenda of all countries of the world. We hope that the results of our study will serve as a guide for the policies that countries will determine in case of epidemics.

Conflict of Interest: No conflict of interest was declared by the authors.

Peer-review: Externally peer-reviewed.

\section{REFERENCES}

1) Liu J, Liao $X$, Qian $S$, et al. Community transmission of severe acute respiratory syndrome coronavirus 2, Shenzhen, China, 2020. Emerg Infect Dis 2020; 26 (6): 1320-1323.

2) World Health Organization. Modes of transmission of virus causing COVID-19: implications for IPC precaution recommendations: scientific brief (2020, March 29).

https://apps.who.int/iris/handle/10665/331616 [Cited 2020 June 30].

3) International Monetary Fund. Policy responses to Covid-19 https://www.imf.org/en/Topics/imf-andcovid19/Policy-Responses-to-COVID-19 . [Cited 2020 June 30].

4) Liu K, Chen $Y$, Lin R, Han K. Clinical features of COVID-19 in elderly patients: a comparison with young and middle-aged patients. J Infect 2020; 80 (6): 14-18.

5) Ministry of Interior, Republic of Turkey. Circular of curfew for people who have 65 years and older and chronic illness (2020, March 21). https://www.icisleri.gov.tr/65-yas-ve-]ustu-ilekronik-rahatsizligiolanlara-sokaga-cikma-yasagigenelgesi [Cited 2020 March 30]

6) Santini ZI, Jose PE, Cornwell EY, et al. Social disconnectedness, perceived isolation, and symptoms of depression and anxiety among older Americans (NSHAP): a longitudinal mediation analysis. Lancet Public Health 2020; 5(1): e62-70. 
7) Zhang $Y$, Chen $Y$, Ma L. Depression and cardiovascular disease in elderly: Current understanding. J Clin Neurosci 2018; 47: 1-5.

8) Alexopoulos GS. Depression in the elderly. Lancet 2005; 365 (9475): 1961-1970.

9) Ministry of Health, Republic of Turkey, Covid-19 Information Page. https://covid19.saglik.gov.tr/TR-66935/genelkoronavirus-tablosu.html [Cited 2020 December 5].

10) Ministry of Interior, Republic of Turkey. (Circular dated 2020, November 18 and numbered 19161). https://www.icisleri.gov.tr/koronavirus-salginiyeni-tedbirler [Cited 2020 November 18]

11) Yesavage JA, Sheik JI. Geriatric Depression Scale (GDS) recent evidence and development of a shorter version. Clin Gerontol 1986; 5(1/2): 165-173.

12) Durmaz $B$, Soysal $P$, Ellidokuz $H$, Işık AT. Validity and reliability of geriatric depression scale-15 (short form) in Turkish older adults. North Clin Istanb 2018; 5(3): 216-220.

13) Greenberg SA. How to try this: The Geriatric Depression Scale (GDS): Short Form. Am J Nurs 2007; 107(10): 60-69.

14) Ahmed Z, Ahmed O, Aibao Z, Hanbin S, Siyu L, Ahmad A. Epidemic of COVID-19 in China and associated psychological problems. Asian J Psychiatr, 2020; 51: 102092.

15) Huang $Y$, Zhao N. Generalized anxiety disorder, depressive symptoms and sleep quality during COVID-19 outbreak in China: a web-based cross-sectional survey. Psychiatr Res 2020; 288: 112954.

16) Ozamiz-Etxebarria N, Dosil-Santamaria $M$, Picaza-Gorrochategui $\mathrm{M}$, Idoiaga-Mondragon $\mathrm{N}$. Stress, anxiety, and depression levels in the initial stage of the COVID-19 outbreak in a population sample in the northern Spain. Cad Saude Publica 2020; 36 (4): e00054020.

17) Weyerer $S$, Eifflaender-Gorfer $S$, Wiese $B$, et al. Incidence and predictors of depression in nondemented primary care attenders aged 75 years and older: results from a 3-year follow-up study. Age Ageing 2013; 42 (2): 173-180.

18) García-Portilla $P$, Tomás LF, Bobes-Bascarán $T$, et al. Are older adults also at higher psychological risk from COVID-19? Aging Ment Health 2020; 1 : 1-8.
19) Salk RH, Hyde JS, Abramson LY. Gender differences in depression in representative national samples: meta-analyses of diagnoses and symptoms. Psychol Bull 2017; 143(8): 783822.

20) Lee J. Pathways from education to depression. J Cross Cult Gerontol 2011; 26(2): 121-135.

21) Canbal $M$, Şencan $I$, Şahin $A$, Kunt Ş, Çavuş UY, Tekin O. Effects of depression and life factors on social network score in elderly people in Çankaya, Ankara. Turk J Med Sci 2012; 42(4): 725-731.

22) Özdin S, Bayrak Özdin Ş. Levels and predictors of anxiety, depression and health anxiety during COVID-19 pandemic in Turkish society: The importance of gender. Int J Soc Psychiatr 2020; 66(5): 504-511.

23) Coughlin SS. Anxiety and depression: Linkages with viral diseases. Public Health Rev 2012; 34(2): 7.

24) Jalloh MF, Li W, Bunnell RE, et al. Impact of Ebola experiences and risk perceptions on mental health in Sierra Leone. BMJ Global Health, 2018; 3(2): e000471.

25) Saadatian-Elahi M, Facy F, Del Signore C, Vanhems P. Perception of epidemic's related anxiety in the General French Population: A cross-sectional study in the Rhône-Alpes region. BMC Public Health 2010; 10(1): 191.

26) Bults M, Beaujean DJ, Zwart O, et al. Perceived risk, anxiety, and behavioral responses of the general public during the early phase of the Influenza A (H1N1) pandemic in the Netherlands: Results of three consecutive online surveys. BMC Public Health 2011; 3(11): 2.

27) Brooks SK, Webster RK, Smith LE, et al. The psychological impact of quarantine and how to reduce it: rapid review of the evidence. Lancet 2020; 395: 912-920.

28) Rothstein B, Uslaner EM. All for all: Equality, corruption, and social trust. World Politics 2005; 58(1): 41-72.

29) Shigemura J, Ursano RJ, Morganstein JC, Kurosawa M, Benedek DM. Public responses to the novel 2019 coronavirus (2019-nCoV) in Japan: mental health consequences and target populations. Psychiatry Clin Neurosci 2020; 74(4): 281-282. 